\title{
Communication \\ Utilization of Hematite Particles for Economical Removal of $o$-xylene in a High-Temperature Gas-Solid Reactor
}

\author{
Xiaolong Ma ${ }^{1}$, Dandan Zhao ${ }^{2}$, Jinjin Qian ${ }^{2}$, Zichuan Ma ${ }^{2, *(\mathbb{D})}$ and Jiansheng Cui ${ }^{1, *}$ \\ 1 School of Environmental Science and Engineering, Hebei University of Science and Technology, \\ Shijiazhuang 050018, China; maxiaolong2410@hebust.edu.cn \\ 2 Hebei Key Laboratory of Inorganic Nano-Materials, College of Chemistry and Material Sciences, Hebei \\ Normal University, Shijiazhuang 050024, China; zhaoddv@163.com (D.Z.); qianjinjin0209@163.com (J.Q.) \\ * Correspondence: mazc@hebtu.edu.cn (Z.M.); cuijiansheng@hebust.edu.cn (J.C.); \\ Tel.: +86-0311-8078-7400 (Z.M.)
}

check for updates

Citation: Ma, X.; Zhao, D.; Qian, J.; Ma, Z.; Cui, J. Utilization of Hematite Particles for Economical Removal of $o$-xylene in a High-Temperature Gas-Solid Reactor. Molecules 2022, 27, 1509. https://doi.org/10.3390/ molecules27051509

Academic Editor: Dimitrios Bikiaris

Received: 27 January 2022

Accepted: 22 February 2022

Published: 23 February 2022

Publisher's Note: MDPI stays neutral with regard to jurisdictional claims in published maps and institutional affiliations.

Copyright: (c) 2022 by the authors. Licensee MDPI, Basel, Switzerland. This article is an open access article distributed under the terms and conditions of the Creative Commons Attribution (CC BY) license (https:// creativecommons.org/licenses/by/ $4.0 /)$.

\begin{abstract}
To establish a novel approach for VOCs resource utilization, coupled $o$-xylene oxidation and hematite reduction was investigated in this study in a high-temperature gas-solid reactor in the temperature range $300-700{ }^{\circ} \mathrm{C}$. As the $o$-xylene-containing inert gas $\left(\mathrm{N}_{2}\right)$ stream traveled through the hematite particle bed, its reaction behavior was determined in programmed heating and constant temperature modes. Consequently, the effect of bed temperature, flow rate and $o$-xylene inlet concentration on both $o$-xylene removal performance and degree of hematite reduction was studied. The raw hematite and solid products were analyzed by TGA, XRF, XRD and SEM-EDS. The results showed that a temperature above $300{ }^{\circ} \mathrm{C}$ was required to completely eliminate $o$-xylene by hematite, and both $o$-xylene removal capacity and degree of hematite reduction at $5 \%$ breakthrough points enhanced on increasing the temperature and decreasing the flow rate. The increment in temperature from $300{ }^{\circ} \mathrm{C}$ to $700{ }^{\circ} \mathrm{C}$ led to a gradual reduction of $\mathrm{Fe}_{2} \mathrm{O}_{3}$ to $\mathrm{Fe}_{3} \mathrm{O}_{4}, \mathrm{FeO}$ and metallic iron. Thus, this study provides a novel, economic and promising technology for treating the VOC pollutants.
\end{abstract}

Keywords: $o$-xylene; hematite; reduction; removal; metallic iron

\section{Introduction}

Volatile organic compounds (VOCs) are toxic pollutants, which are released in the environment through industrial emissions. As important contributors to particulate matter, surface ozone and secondary organic aerosols [1,2], their emissions are subjected to stringent legal restrictions $[3,4]$. Therefore, the development of new technologies to prevent the VOC contamination is currently of significant interest [5-8]. Among these, the processes that can enable the achievement of VOC resource utilization are a key to move towards sustainability; thus, these have received an increasing attention in recent years [9-14]. Considering that the mainstream technologies for VOCs elimination such as catalytic oxidation and thermal combustion are based on VOCs oxidation reactions, it is suspected that VOCs have a potential as reducing agents in the iron-making process from iron oxide ores.

Steel is the most commonly used material in today's society, though its generation requires a significant amount of direct reduced iron (DRI) as the metal source. DRI is also known as sponge iron or pig iron, which has traditionally been produced through the reduction of iron ore using fossil fuels (coal and natural gas) as reducing agent and energy supply, thus, significantly contributing to the $\mathrm{CO}_{2}$ emissions in metallurgical industries $[15,16]$. As biomass is the most abundant, renewable and $\mathrm{CO}_{2}$ neutral resource, a number of research studies have explored the utilization of biomass and its derivatives (char or volatiles) for preparing DRI [17-19]. Bagatini et al. [20] demonstrated that biomass volatiles can serve as a viable reducing agent to reduce $\mathrm{CO}_{2}$ emissions in the industry. In fact, biomass volatiles mainly include non-condensable gases $\left(\mathrm{CO}, \mathrm{H}_{2}, \mathrm{CH}_{4}, \mathrm{C}_{2} \mathrm{H}_{6}, \mathrm{C}_{2} \mathrm{H}_{4}, \mathrm{C}_{2} \mathrm{H}_{2}, \mathrm{CO}_{2}\right.$, 
etc.) and liquid products (tar and oil like alkanes, aromatic hydrocarbons, alcohols, ethers, aldehydes, ketones, carboxylic acids, etc.), most of which belong to the VOC family in terms of their physiochemical properties [21,22]. Therefore, the reduction of iron oxides by VOCs can offer advantages for achieving multiple targets such as the purification and resource utilization of VOCs, acquisition of DRI co-product and carbon emission reduction during the iron-making process. For these reasons, the iron oxide oxidation-based approach differs from those already published in the literature in both process principle and material used. Among different types of iron oxides, hematite $\left(\mathrm{Fe}_{2} \mathrm{O}_{3}\right)$ has the most abundant lattice oxygen. In this study, thus, a naturally hematite iron ore (HIO) was selected as the potential oxidizing agent to explore the feasibility of its reduction using 0 -xylene as a model VOC and investigate the effect of several process conditions on both $o$-xylene removal performance and hematite conversion. The results obtained in this study can provide a beneficial foundation for developing novel pathways for VOC resource utilization.

\section{Results and Discussion}

\subsection{Reactivity of HIO with o-xylene}

The chemical composition of HIO used in this study is presented in Table 1. The total iron content was $40.94 \%$, whereas the content of $\mathrm{Fe}_{2} \mathrm{O}_{3}$ and iron lattice oxygen was calculated to be $58.53 \%$ and $17.59 \%$ respectively. As o-xylene passed through the heating $\mathrm{HIO}$ bed, $\mathrm{Fe}_{2} \mathrm{O}_{3}$ was reduced to iron species with low valence states $\left(\mathrm{Fe}_{3} \mathrm{O}_{4}, \mathrm{FeO}\right.$ and $\mathrm{Fe}$ ), while it was oxidized to $\mathrm{CO}_{2} / \mathrm{CO}$ and $\mathrm{H}_{2} \mathrm{O}$, thus, achieving the dual goals of iron ore reduction and $o$-xylene removal. Figure 1 shows the plot of $o$-xylene removal ratios $\left(X_{o-\mathrm{x}}\right)$ vs. temperature $(T)$ for depicting the reactive removal profile of $\mathrm{HIO}$ for $o$-xylene as a function of temperature. The profile could be divided into three regions: an adsorption-desorption region $\left(<190^{\circ} \mathrm{C}\right)$, an activation region $\left(190 \sim 300{ }^{\circ} \mathrm{C}\right)$ and a reactive region $\left(300 \sim 700^{\circ} \mathrm{C}\right)$. In the adsorption-desorption region, a high $X_{o-x}$ value was observed for $o$-xylene removal followed by a decline, which could be attributed to the physisorption process at low temperatures and thermal desorption at high temperatures. The amount of $o$-xylene removed by $\mathrm{HIO}$ increased with temperature in the activation region. Importantly, the reactive region covered a very wide temperature range $\left(300 \sim 700{ }^{\circ} \mathrm{C}\right)$, and $o$-xylene was almost completely removed. It is important to note that, limited by the experimental conditions, the tests were performed before $700{ }^{\circ} \mathrm{C}$. The results confirmed that $\mathrm{HIO}$ exhibited a quite high reactivity for $o$-xylene above $300^{\circ} \mathrm{C}$.

Table 1. Chemical composition of HIO (mass \%).

\begin{tabular}{ccccccccccccc}
\hline Components & $\mathbf{F e}$ & $\mathbf{O}$ & $\mathbf{S i}$ & $\mathbf{A l}$ & $\mathbf{P}$ & $\mathbf{C a}$ & $\mathbf{S r}$ & $\mathbf{M g}$ & $\mathbf{M n}$ & $\mathbf{K}$ & $\mathrm{Ti}$ & Others \\
\hline Content & 40.94 & 35.41 & 9.63 & 4.06 & 1.16 & 1.71 & 0.76 & 0.46 & 0.56 & 0.56 & 0.22 & 4.53 \\
\hline
\end{tabular}

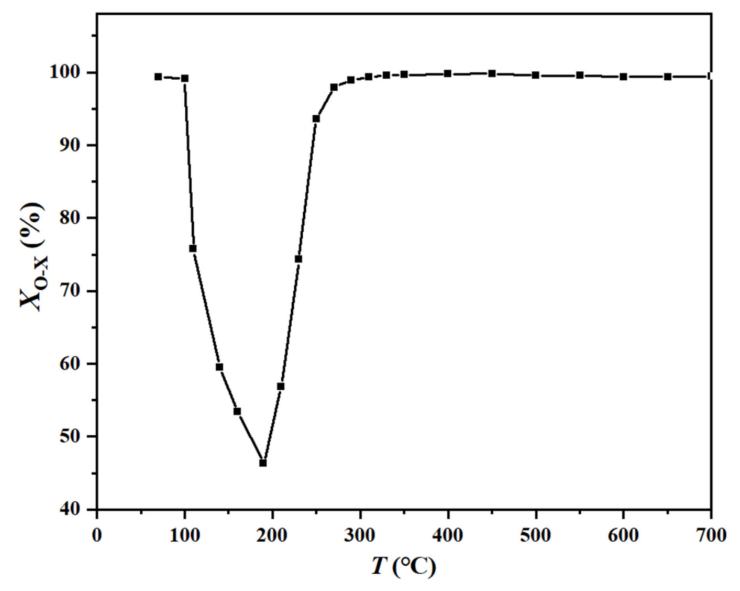

Figure 1. The plot of $o$-xylene removal ratios vs. temperature. 


\subsection{Effect of Temperature on o-xylene Removal and HIO Conversion}

To study the effect of temperature on $o$-xylene removal and HIO conversion, a group of reaction breakthrough curves were measured at $300,400,500,600$ and $700{ }^{\circ} \mathrm{C}$ (Figure 2a,b), in which the end point was set at $X_{o-x}=5 \%$. Except for the experiment at $700{ }^{\circ} \mathrm{C}$, each reaction breakthrough curve (Figure 2a) demonstrated an initial lag phase as well as a concave upward shape indicative of efficient removal ability, high filled bed utilization and process rate [23]. The calculated process parameters are listed in Table 2. As observed, $Q_{\text {B }}$ exhibited a significant increase with temperature. Especially at $700{ }^{\circ} \mathrm{C}$, the $o$-xylene breakthrough from the HIO bed remained unseen until $54 \mathrm{~h}$, and the process curve was also different as compared to the curves acquired at lower temperatures (Figure 2b), thus, implying that $\mathrm{HIO}$ might have possessed super capacity (more than $691 \mathrm{mg} \mathrm{g}[\mathrm{Fe}]^{-1}$ ) and unique reaction mechanism for removing $o$-xylene, which need to be studied further. Comparing $Q_{\mathrm{B}}$ of $\mathrm{HIO}$ for removing $o$-xylene with other materials already reported in the literature [9-12], the value obtained here was higher.
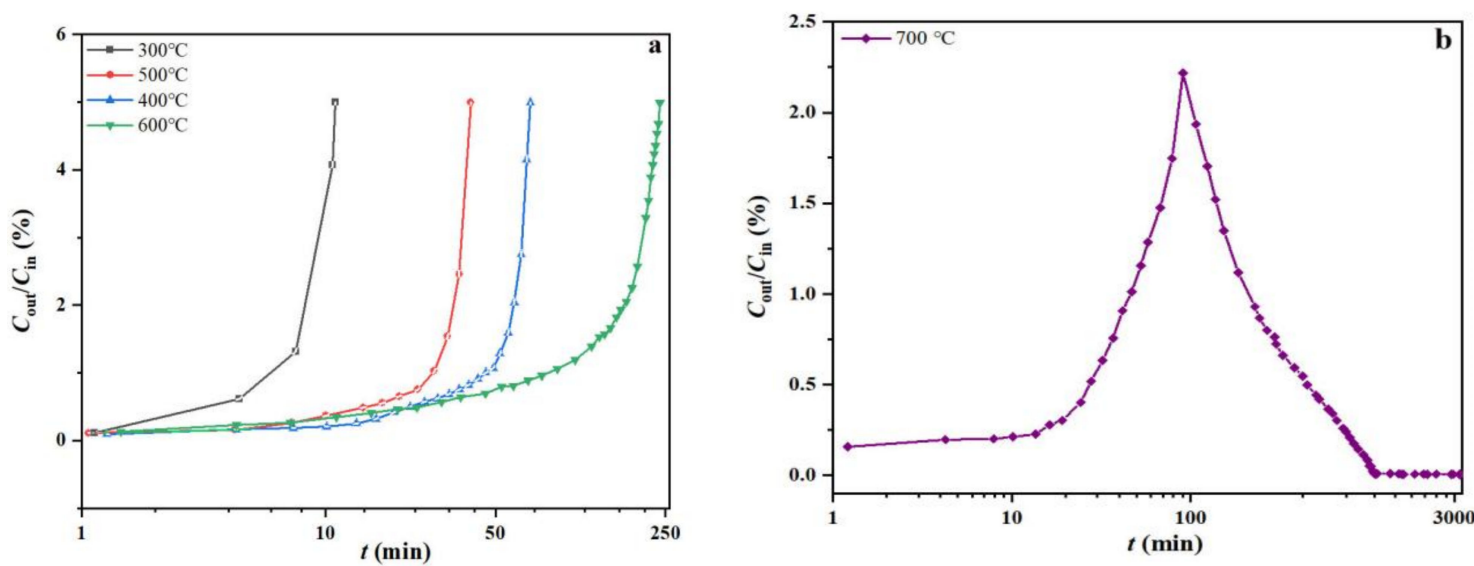

Figure 2. The reaction breakthrough curves of $o$-xylene at four different temperatures ranging $300-600{ }^{\circ} \mathrm{C}(\mathbf{a})$ and $700{ }^{\circ} \mathrm{C}(\mathbf{b})$.

Table 2. Parameters for 0 -xylene removal and $\mathrm{HIO}$ conversion at different temperatures.

\begin{tabular}{cccccc}
\hline \multirow{2}{*}{ Parameters } & \multicolumn{5}{c}{ Temperature for Obtaining Product $\left({ }^{\circ} \mathbf{C}\right)$} \\
\cline { 2 - 5 } & $\mathbf{3 0 0}$ & $\mathbf{4 0 0}$ & $\mathbf{5 0 0}$ & $\mathbf{6 0 0}$ & $\mathbf{7 0 0}$ \\
\hline$t_{\mathrm{B}}(\mathrm{min})$ & 11.00 & 39.62 & 69.65 & 237.32 & $3240^{\mathrm{a}}$ \\
$Q_{\mathrm{B}}\left(\mathrm{mg} \mathrm{g}[\mathrm{Fe}]^{-1}\right)$ & 2.32 & 8.38 & 14.73 & 49.88 & $691^{\mathrm{a}}$ \\
$\mathrm{RD}(\%)$ & 2.79 & 14.05 & 15.73 & 36.68 & - \\
\hline
\end{tabular}

a artificial cutoff time in this study and its corresponding adsorption amount. -: not calculated due to the carbon deposition.

The obtained HIO mass loss due to the reduction by $o$-xylene, combined with TGA (Supplementary Material, Figure S1) and carbon data (Supplementary Material, Figure S2), allowed an estimation of the reduction degree (RD) at different temperatures. The estimated results are presented in Table 2, except for the experiment at $700{ }^{\circ} \mathrm{C}$. In the temperature range $300-600{ }^{\circ} \mathrm{C}$, $\mathrm{RD}$ was observed to increase with temperature, thus, exhibiting a similar behavior as $Q_{\mathrm{B}}$. At $300{ }^{\circ} \mathrm{C}$, the results demonstrated only a minor reduction $(2.79 \%)$, which was even lower than the theoretical $\mathrm{RD}$ value of $\mathrm{Fe}_{2} \mathrm{O}_{3}$ to $\mathrm{Fe}_{3} \mathrm{O}_{4}(11.1 \%)$. Thus, it was speculated that the sample derived from the reaction at $300{ }^{\circ} \mathrm{C}$ was composed of $\mathrm{Fe}_{2} \mathrm{O}_{3}$ and $\mathrm{Fe}_{3} \mathrm{O}_{4}$. At 400 and $500{ }^{\circ} \mathrm{C}$, the $\mathrm{RD}$ values were observed to increase respectively to $14.05 \%$ and $15.73 \%$, which were slightly higher than the theoretical RD value of $\mathrm{Fe}_{2} \mathrm{O}_{3}$ to $\mathrm{Fe}_{3} \mathrm{O}_{4}$ $(11.1 \%)$. However, the values were significantly smaller than that of $\mathrm{Fe}_{3} \mathrm{O}_{4}$ to $\mathrm{FeO}(33.3 \%)$, thus, implying that the conversion product was predominantly $\mathrm{Fe}_{3} \mathrm{O}_{4}$ with a small amount of $\mathrm{Fe}_{2} \mathrm{O}_{3}$ or $\mathrm{FeO}$. As the process was conducted at $600{ }^{\circ} \mathrm{C}$, the $\mathrm{RD}$ value of $\mathrm{HIO}$ reached $36.68 \%$, which was slightly higher than the theoretical RD value of $\mathrm{Fe}_{2} \mathrm{O}_{3}$ to $\mathrm{FeO}(33.3 \%$ ), 
thereby suggesting that $\mathrm{FeO}$ was the main conversion product. Indeed, these notions were also confirmed by XRD analysis. Figure 3 presents the XRD patterns and phases of $\mathrm{HIO}$ and its conversion products at various temperatures. $\mathrm{SiO}_{2}$ (quartz, JCPDS 85-0798) was detected in all samples, however, with secondary importance in terms of intensity. $\mathrm{SiO}_{2}$ represents an inherent mineral impurity present in the pristine $\mathrm{HIO}$ and remains unchanged during the reactions with $o$-xylene. In terms of the iron species in the samples, $\mathrm{HIO}$ solely possessed $\mathrm{Fe}_{2} \mathrm{O}_{3}$ (hematite, syn, JCPDS 89-0597). On the other hand, the sample at $300{ }^{\circ} \mathrm{C}$ had $\mathrm{Fe}_{2} \mathrm{O}_{3}$ as the main phase but with a small amount of $\mathrm{Fe}_{3} \mathrm{O}_{4}$ (magnetite, JCPDS 99-0073). At $400{ }^{\circ} \mathrm{C}$, both $\mathrm{Fe}_{2} \mathrm{O}_{3}$ and $\mathrm{Fe}_{3} \mathrm{O}_{4}$ became the main phases, whereas $\mathrm{Fe}_{2} \mathrm{O}_{3}$ turned into $\mathrm{Fe}_{3} \mathrm{O}_{4}$ as the temperature was raised to $500{ }^{\circ} \mathrm{C}$. Further increasing the temperature $\left(600{ }^{\circ} \mathrm{C}\right)$ led to the conversion of a majority of $\mathrm{Fe}_{3} \mathrm{O}_{4}$ into $\mathrm{FeO}$ (iron oxide, JCPDS 77-2355) and the formation of a small amount of metallic Fe (iron, JCPDS 99-0064). For the product obtained at $700{ }^{\circ} \mathrm{C}$ after $54 \mathrm{~h}$ (still remaining in the non-breakthrough state), both metallic Fe and quartz phases were detected in the XRD patterns. However, the EDS spectrum (Supplementary Material, Figure S2) of the product at $700{ }^{\circ} \mathrm{C}$ (using a mixture of $90 \% \mathrm{HIO}$ and $10 \%$ pure carbon powder as the standard sample) revealed that it also possessed up to $10.8 \%$ carbon apart from $\mathrm{Fe}, \mathrm{O}, \mathrm{Si}, \mathrm{Al}$ derived from the pristine $\mathrm{HIO}$. As a comparison (Supplementary Material, Figure S2), only $0.34 \%$ carbon was observed in the EDS spectrum of the product at $600{ }^{\circ} \mathrm{C}$, while no carbon deposition occurred at lower temperatures. The results demonstrated that the interaction of $o$-xylene with metallic Fe at $700{ }^{\circ} \mathrm{C}$ led to a significant level of carbon deposition, thus, resulting in the high $o$-xylene removal ability of hematite and getting a mixture of iron and carbon. Such a mixture is well known as a virgin source for high quality steel production, and its use can be effective in decreasing $\mathrm{CO}_{2}$ emissions in existing plants $[16,24]$.

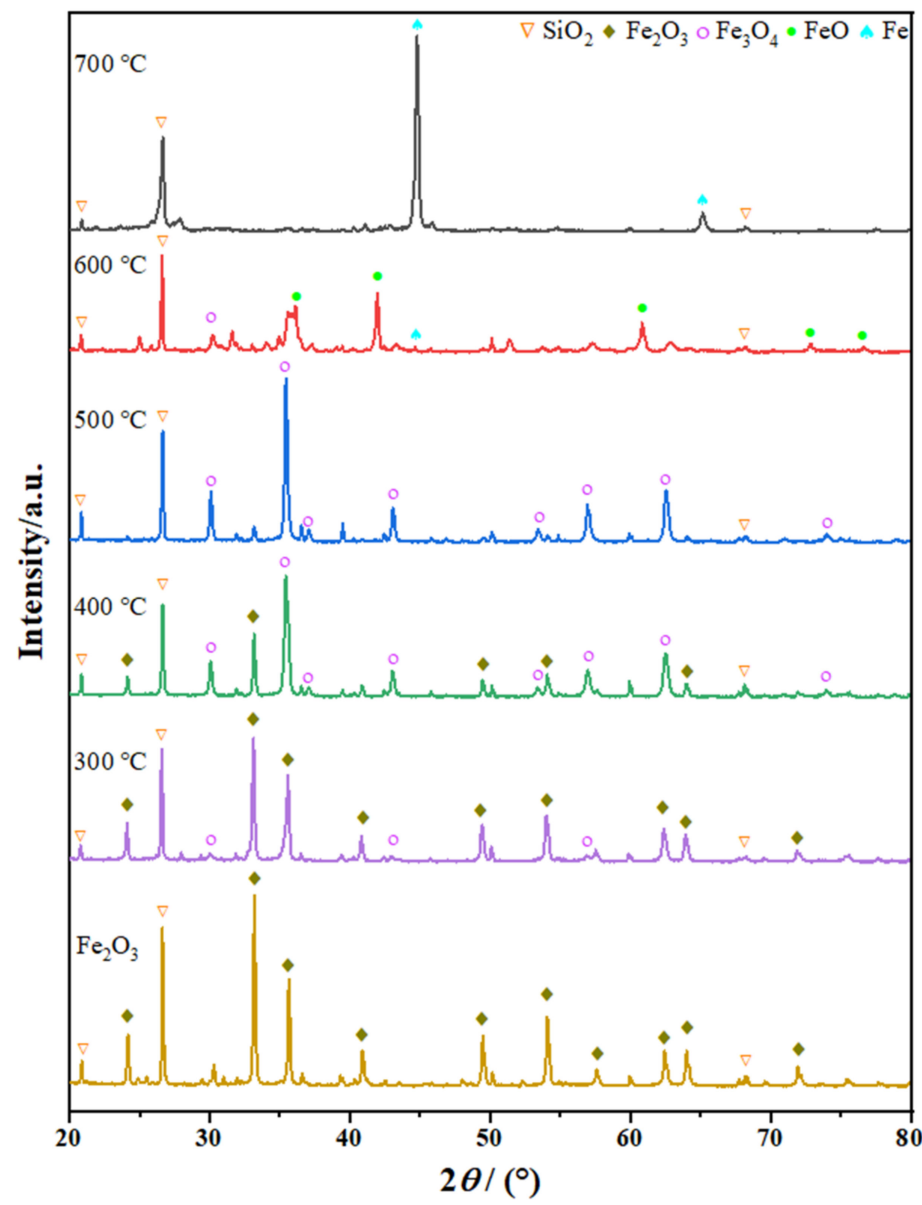

Figure 3. XRD patterns of $\mathrm{HIO}$ and its conversion products at different temperatures. 


\subsection{Effect of Flow Rate on o-xylene Removal and HIO Conversion}

The effect of flow rate $\left(V_{\mathrm{g}}\right)$ on the $o$-xylene removal and degree of reduction in the $\mathrm{HIO}$ filled bed (bed length $=5.0 \mathrm{~cm}$ ) was studied by varying the $V_{\mathrm{g}}$ value from 50 to $150 \mathrm{~mL} \mathrm{~min}^{-1}$ at $600{ }^{\circ} \mathrm{C}$ and a fixed $C_{\text {in }}$ value of $7.0 \mathrm{mg} \mathrm{L}^{-1}$. The reaction breakthrough curves and corresponding process parameters are shown in Figure 4 and Table 3. The parameters $t_{\mathrm{B}}, Q_{\mathrm{B}}$ and RD were observed to decline on increasing $V_{\mathrm{g}}$. At a relatively low $V_{\mathrm{g}}$ value, $\mathrm{HIO}$ experienced a greater contact time with $o$-xylene in gaseous stream for carrying out the redox reaction. As the $V_{\mathrm{g}}$ value was increased, $o$-xylene molecules had a much shorter contact time for the redox reaction, which resulted in a poor degree of $\mathrm{HIO}$ reduction. Therefore, short $t_{\mathrm{B}}$ as well as low $Q_{\mathrm{B}}$ and $\mathrm{RD}$ were observed at the high flow rates.

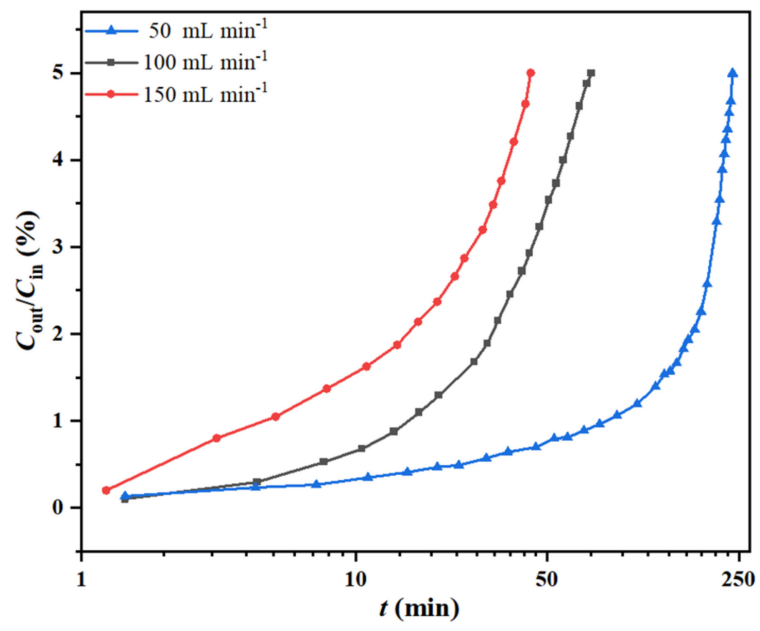

Figure 4. Reaction breakthrough curves of $o$-xylene at different flow rates.

Table 3. Parameters for $o$-xylene removal and HIO conversion as a function of $V_{\mathrm{g}}$ and $C_{\mathrm{in}}$.

\begin{tabular}{ccccccc}
\hline \multirow{2}{*}{ Parameters } & \multicolumn{3}{c}{$V_{\mathrm{g}}\left(\mathbf{m L ~ \mathbf { ~ m i n } ^ { - 1 } )}\right.$} & \multicolumn{3}{c}{$C_{\text {in }}\left(\mathbf{m g ~ L}^{-1}\right)$} \\
\cline { 2 - 7 } & $\mathbf{5 0}$ & $\mathbf{1 0 0}$ & $\mathbf{1 5 0}$ & $\mathbf{3 . 5}$ & $\mathbf{7 . 0}$ & $\mathbf{9 . 6}$ \\
\hline$t_{\mathrm{B}}(\mathrm{min})$ & 237.32 & 72.48 & 43.58 & 238.08 & 237.32 & 62.69 \\
$Q_{\mathrm{B}}\left(\mathrm{mg} \mathrm{g}^{-1}\right)$ & 49.88 & 30.21 & 27.21 & 23.74 & 49.88 & 18.00 \\
$\left.\mathrm{RD}^{-1} \%\right)$ & 36.68 & 26.74 & 23.72 & 31.47 & 36.68 & 26.54 \\
\hline
\end{tabular}

\subsection{Effect of Inlet Concentration of o-xylene on Its Removal and HIO Conversion}

The effect of $C_{\text {in }}\left(3.5,7.0\right.$ and $\left.9.6 \mathrm{mg} \mathrm{L}^{-1}\right)$ on the $o$-xylene removal and degree of reduction in the $\mathrm{HIO}$ filled bed was analyzed at $600{ }^{\circ} \mathrm{C}, V_{\mathrm{g}}$ of $50 \mathrm{~mL} \mathrm{~min}{ }^{-1}$ and bed length of $5.0 \mathrm{~cm}$. The results are shown in Figure 5 , and the process parameters are also presented in Table 3. As observed, $t_{\mathrm{B}}$ at $3.5 \mathrm{mg} \mathrm{L}^{-1} C_{\mathrm{in}} \approx$ that of $7.0 \mathrm{mg} \mathrm{L}^{-1}>>$ that of $9.6 \mathrm{mg} \mathrm{L}^{-1}$. Both $Q_{\mathrm{B}}$ and $\mathrm{RD}$ were observed to reach their maximum values at $7.0 \mathrm{mg} \mathrm{L}^{-1}$. At a constant residence time, the rate of reaction of $o$-xylene with $\mathrm{HIO}$ increased with inlet concentration, thereby decreasing $t_{\mathrm{B}}$ [25]. However, the driving force and rate of the $o$-xylene oxidation were higher at higher $C_{\text {in }}$ values, thus, facilitating the $o$-xylene elimination. Hence, the combination of these two factors provided the maximum $Q_{B}$ and $R D$ values $\left(7.0 \mathrm{mg} \mathrm{L}^{-1}\right)$. 


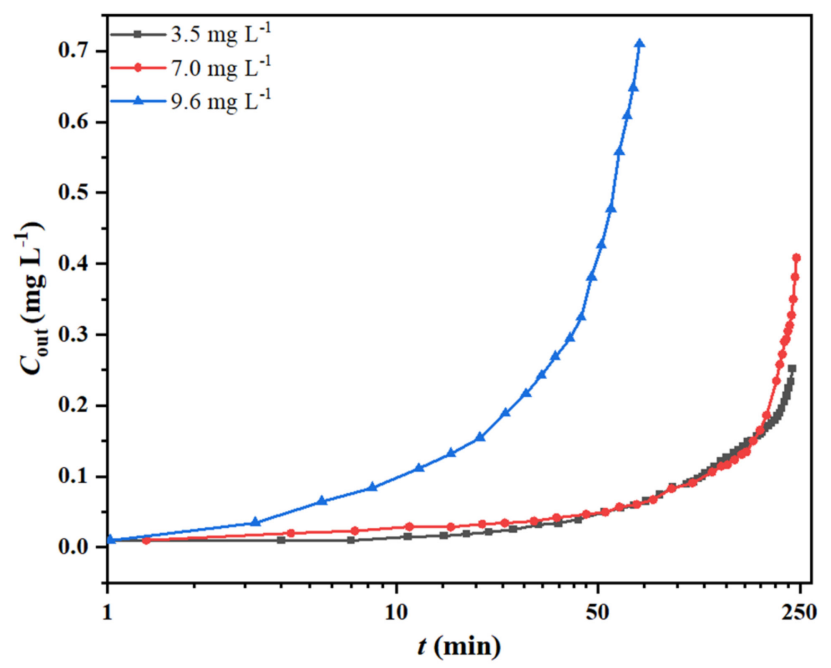

Figure 5. Reaction breakthrough curves of $o$-xylene at different inlet concentrations.

\section{Materials and Methods}

\subsection{Materials}

o-xylene (analytical grade; Tianjin Kermel Chemical Reagent Co. Ltd., Tianjin, China) was used without further purification. HIO powder was purchased from Shanghai New Materials Co. Ltd., Shanghai, China. Its chemical composition was determined by XRF analysis. For this purpose, it was dried at $105{ }^{\circ} \mathrm{C}$, followed by pressing into circular discs by using a tableting machine. Subsequently, it was ground in an agate mortar and sieved to a particle size between 250 and $830 \mu \mathrm{m}$. High purity nitrogen gas (99.999\%; Shijiazhuang Xisanjiao Practical Gas Co. Ltd., Shijiazhuang, China) was used as a carrying and purging gas.

\subsection{Experimental Setup and Procedure}

The experiments to evaluate the $o$-xylene oxidation and $\mathrm{HIO}$ reduction were carried out in a horizontal tube furnace with an internal quartz tube of $10 \mathrm{~mm}$ diameter for heating the packed HIO particles, as shown in the schematic diagram in Figure 6. Prior to each test, $4.0 \mathrm{~g} \mathrm{HIO}$ was packed in the central zone of the quartz tube and inserted in the furnace. The flow rate of $o$-xylene-containing $\mathrm{N}_{2}$ was controlled by using a flow meter (Sevenstar, D07-26, Beijing, China), and the concentration of $o$-xylene was monitored using a GC7900 gas chromatograph (Tianmei, Shanghai, China) equipped with a polyethylene glycol (PEG)$20 \mathrm{M}$ capillary column $(30 \mathrm{~m} \times 0.32 \mathrm{~mm}$ i.d. $)$ and a flame ionization detector. To investigate the $o$-xylene removal performance by $\mathrm{HIO}$ and effects of primary process conditions, three separate experiments were performed:

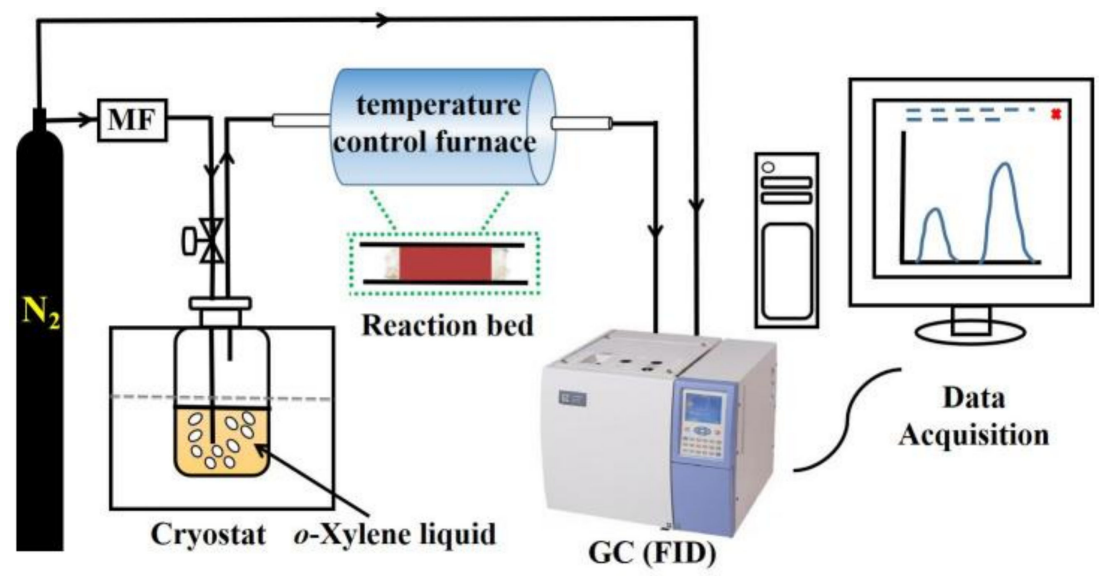

Figure 6. Schematic diagram of experimental setup. 
(1) The reactivity was examined using a temperature-programmed mode from ambient temperature to $700{ }^{\circ} \mathrm{C}$ at a rate of $5^{\circ} \mathrm{C} \mathrm{min}{ }^{-1}$. The gas flow rate $\left(V_{\mathrm{g}}\right)$ of $50 \mathrm{~mL} \mathrm{~min}{ }^{-1}$ and $o$-xylene inlet concentration $\left(C_{\text {in }}\right)$ of $7.0 \mathrm{mg} \mathrm{L}^{-1}$ were used. The results were presented in the form of a plot of $o$-xylene removal ratios $\left(X_{o-x}\right)$ vs. temperature $(T)$; where $X_{o-x}$ was calculated from Equation (1). From the experimental results, it was possible to identify the temperature range of the reactive region for the $o$-xylene-hematite system.

(2) The reaction breakthrough curves were obtained at a constant flow rate of $50 \mathrm{~mL} \mathrm{~min} \mathrm{~m}^{-1}$ and an inlet concentration of $7.0 \mathrm{mg} \mathrm{L}^{-1}$ by varying the bed temperature in the temperature range of the reactive region to analyze its effect on the reaction. In this study, the breakthrough time $\left(t_{\mathrm{B}}, \mathrm{min}\right)$ was defined as the time at $C_{\text {out }, \mathrm{t}} / C_{\mathrm{in}}=0.05$, which was also set as an end point for each reaction breakthrough test. From this, the breakthrough removal capacity $\left(Q_{\mathrm{B}}, \mathrm{mg} \mathrm{g}^{-1}\right)$ was calculated by using Equation (2).

(3) Further reaction breakthrough tests of $o$-xylene were carried out by independently varying the flow rate or inlet concentration (all other variables were kept constant).

The reduction degree (RD) was determined for the obtained solid products, as calculated from Equation (3) $[20,26]$.

$$
\begin{gathered}
X_{O-X}=\frac{C_{\text {in }}-C_{\text {out }, t}}{C_{\text {in }}} \times 100 \% \\
Q_{\mathrm{B}}=\frac{V_{\mathrm{g}} C_{\text {in }}}{m_{\mathrm{Fe}}} \int_{0}^{t_{\mathrm{B}}}\left(1-\frac{C_{\text {out }, t}}{C_{\text {in }}}\right) \mathrm{d} t \\
\mathrm{RD}(\%)=\left[\left(m_{\mathrm{i}}-m_{\mathrm{f}}\right)+m_{\mathrm{C}}-W_{\mathrm{s}}\right] \times 100 / m_{\text {Ored }}
\end{gathered}
$$

where $m_{\mathrm{i}}$ and $m_{\mathrm{f}}$ are the initial and final mass of the sample $(\mathrm{g})$, respectively; $m_{\mathrm{Fe}}$ is the mass of the iron element in sample; $t$ is the adsorption time (min); $C_{\text {out }, t}$ is the outlet $o$-xylene concentration in the gas flow $\left(\mathrm{mg} \mathrm{L}^{-1}\right) ; m_{\mathrm{C}}$ and $W_{\mathrm{s}}$ are the carbon content and mass loss of the sample obtained by EDS and TGA analysis, respectively; and $W_{\text {Ored }}$ is the mass of iron lattice oxygen in the raw sample. The other symbols such as $X_{o-\mathrm{x}}, Q_{\mathrm{B}}, t_{\mathrm{B}}, V_{\mathrm{g}}, C_{\mathrm{in}}$ and RD were defined earlier.

\subsection{Characterization of Samples}

The chemical composition of the HIO sample was determined by using X-ray fluorescence spectrometry (XRF; ARL PERFORM'X, Thermo Fisher Scientific, Waltham, MA, USA). The thermogravimetric analysis (TGA) was conducted using a TG/DSC system (PerkinElmer-STA8000 instrument (Fremont, CA, USA)) from 30 to $920{ }^{\circ} \mathrm{C}$ at a rate of $20{ }^{\circ} \mathrm{C} / \mathrm{min}$ under $\mathrm{N}_{2}$ atmosphere with a gas flow of $20 \mathrm{~mL} / \mathrm{min}$. The particle morphology and composition analyses of the samples were performed using a cold-field emission scanning electron microscope (SEM; S-4800, Hitachi, Japan) equipped with an energy dispersive spectrometer (EDS; INCA 350, Hitachi, Japan) accessory. The X-ray diffraction spectra were obtained using a D8 Advance X-ray diffractometer (XRD; Brucker AXS, Karlsruhe, Germany).

\section{Conclusions}

The results presented in this study demonstrate the potential of using hematite ore as an oxidizer for simultaneously removing $o$-xylene gas and reducing iron oxides in the reactive region $\left(300 \sim 700{ }^{\circ} \mathrm{C}\right)$. The removal capacity was found to be dependent on the temperature, flow rate and inlet concentration, while the conversion products of $\mathrm{Fe}_{2} \mathrm{O}_{3}$ mainly depended on the temperature. The increment in temperature from $300{ }^{\circ} \mathrm{C}$ to $700{ }^{\circ} \mathrm{C}$ led to a gradual reduction of $\mathrm{Fe}_{2} \mathrm{O}_{3}$ to $\mathrm{Fe}_{3} \mathrm{O}_{4}, \mathrm{FeO}$ and metallic iron, and the degree of reduction increased in turn. At $600{ }^{\circ} \mathrm{C}$, the $Q_{\mathrm{B}}$ value reached $49.88 \mathrm{mg} \mathrm{g}[\mathrm{Fe}]^{-1}$, while the value exceeded $691 \mathrm{mg} \mathrm{g}[\mathrm{Fe}]^{-1}$ at the temperature up to $700{ }^{\circ} \mathrm{C}$. The reduction products obtained from hematite, especially the mixture of metallic iron and carbon, are expected to be used as raw materials for the iron- and steel-making industries. Therefore, the findings observed in the current study offer a potential novel strategy for the purification 
and resource utilization of the VOC exhaust gas. Future efforts may further explore the applicability of the approach for more types of VOCs and its practical application.

Supplementary Materials: The following supporting information can be downloaded online. Figure S1: TGA thermogram of HIO; Figure S2: SEM images and EDS spectra of the products at different temperatures.

Author Contributions: This work was carried out in collaboration between all authors. Authors X.M., D.Z. and J.Q. performed the experimental investigation. Authors X.M. and D.Z. performed the data curation and the analysis and wrote the first draft of the manuscript. Corresponding Author J.C. performed the writing-review and editing. Corresponding Author Z.M. performed the writingreview and editing, the project administration and the funding acquisition. All authors have read and agreed to the published version of the manuscript.

Funding: This work was financially supported by the National Natural Science Foundation of China (22176049), the Natural Science Foundation of Hebei Province (B2021205022).

Institutional Review Board Statement: Not applicable.

Informed Consent Statement: Not applicable.

Data Availability Statement: Data is contained within the article or Supplementary Materials. The data presented in this study are available in Supplementary Materials.

Conflicts of Interest: The authors declare no conflict of interest.

Sample Availability: Sample of the HIO. is available from the authors.

\section{References}

1. Wang, W.J.; Parrish, D.D.; Li, X.; Shao, M.; Liu, Y.; Mo, Z.W.; Lu, S.H.; Hu, M.; Fang, X.; Wu, Y.S.; et al. Exploring the drivers of the increased ozone production in Beijing in summertime during 2005-2016. Atmos. Chem. Phys. 2020, 20, 15617-15633. [CrossRef]

2. Zhan, J.L.; Feng, Z.M.; Liu, P.F.; He, X.W.; He, Z.M.; Chen, T.Z.; Wang, Y.F.; He, H.; Mu, Y.J.; Liu, Y.C. Ozone and SOA formation potential based on photochemical loss of VOCs during the Beijing summer. Environ. Pollut. 2021, 285, 117444. [CrossRef] [PubMed]

3. Lei, R.R.; Sun, Y.M.; Zhu, S.; Jia, Y.C.; Deng, J.L.; Liu, W.B. Investigation on distribution and risk assessment of volatile organic compounds in surface water, sediment, and soil in a chemical industrial park and adjacent area. Molecules 2021, $26,5988$. [CrossRef] [PubMed]

4. $\quad$ Liu, R.Y.; Zhong, M.F.; Zhao, X.Y.; Lu, S.W.; Tian, J.T.; Li, Y.S.; Hou, M.; Liang, X.M.; Huang, H.W.; Fan, L.Y.; et al. Characteristics of industrial volatile organic compounds(VOCs) emission in China from 2011 to 2019. Environ. Sci. 2021, 42, 5169-5179.

5. Hou, X.F.; Zheng, Y.H.; Ma, X.L.; Liu, Y.H.; Ma, Z.C. The Effects of hydrophobicity and textural properties on hexamethyldisiloxane adsorption in reduced graphene oxide aerogels. Molecules 2021, 26, 1130. [CrossRef]

6. Guo, Y.L.; Wen, M.C.; Li, G.Y.; An, T.C. Recent advances in VOC elimination by catalytic oxidation technology onto various nanoparticles catalysts: A critical review. Appl. Catal. B Environ. 2021, 281, 119447. [CrossRef]

7. Liu, B.Y.; Jian, J.; Zhang, B.G.; Huang, W.J.; Gan, Y.L.; Leung, D.Y.C.; Huang, H.B. Catalytic ozonation of VOCs at low temperature: A comprehensive review. J. Hazard. Mater. 2022, 422, 126847. [CrossRef]

8. Lu, S.C.; Liu, Q.L.; Han, R.; Guo, M.; Shi, J.Q.; Song, C.F.; Ji, N.; Lu, X.B.; Ma, D.G. Potential applications of porous organic polymers as adsorbent for the adsorption of volatile organic compounds. J. Environ. Sci. -China 2021, 105, 184-203. [CrossRef]

9. Ma, M.Z.; Gao, K.Y.; Zhao, D.D.; Ma, X.L.; Ma, Z.C. Effect of process conditions on reaction-type adsorption of $o$-xylene by MCM-41 supported sulfuric acid: Model simulations of breakthrough curves. J. Environ. Chem. Eng. 2022, 10, 106937. [CrossRef]

10. Ma, M.Z.; Gao, K.Y.; Ma, Z.C.; Ding, J.H. Influence of preparation method on the adsorptive performance of silica sulfuric acid for the removal of gaseous o-xylene. Sep. Purif. Technol. 2021, 265, 118484. [CrossRef]

11. Gao, K.Y.; Ma, M.Z.; Liu, Y.H.; Ma, Z.C. A comparative study of the removal of $o$-xylene from gas streams using mesoporous silicas and their silica supported sulfuric acids. J. Hazard. Mater. 2021, 409, 124965. [CrossRef]

12. Dong, Y.F.; Liu, Y.H.; Wang, J.Y.; Gao, K.Y.; Ma, Z.C. Silica supported sulfuric acid for the removal of gaseous o-xylene. J. Environ. Chem. Eng. 2019, 7, 102992. [CrossRef]

13. Zhang, H.H.; Dai, L.Y.; Feng, Y.; Xu, Y.H.; Liu, Y.X.; Guo, G.S.; Dai, H.X.; Wang, C.C.; Wang, C.; Hsi, H.C.; et al. A Resource utilization method for volatile organic compounds emission from the semiconductor industry: Selective catalytic oxidation of isopropanol to acetone over $\mathrm{Au} / \alpha-\mathrm{Fe}_{2} \mathrm{O}_{3}$ nanosheets. Appl. Catal. B Environ. 2020, 275, 119011. [CrossRef]

14. Zhang, W.P.; Li, G.Y.; Yin, H.J.; Zhao, K.; Zhao, H.J.; An, T.C. Adsorption and desorption mechanism of aromatic VOCs onto porous carbon adsorbents for emission control and resource recovery: Recent progress and challenges. Environ. Sci. Nano 2022, 9, 81-104. [CrossRef]

15. Zhao, J.; Zuo, H.B.; Wang, Y.J.; Wang, J.S.; Xue, Q.G. Review of green and low-carbon ironmaking technology. Ironmak. Steelmak. 2019, 47, 296-306. [CrossRef] 
16. Wang, P.; Ryberg, M.; Yang, Y.; Feng, K.S.; Kara, S.; Hauschild, M.; Chen, W.Q. Effificiency stagnation in global steel production urges joint supply- and demand-side mitigation efforts. Nat. Commun. 2021, 16, 2066. [CrossRef]

17. Mandova, H.; Gale, W.F.; Williams, A.; Heyes, A.L.; Hodgson, P.; Miah, K.H. Global assessment of biomass suitability for ironmaking-Opportunities for co-location of sustainable biomass, iron and steel production and supportive policies. Sustain. Energy Technol. Assess. 2018, 27, 23-39. [CrossRef]

18. Elkasabi, Y.; Mullen, C.A. Progress on biobased industrial carbons as thermochemical biorefinery coproducts. Energy Fuels 2021, 35, 5627-5642. [CrossRef]

19. Zhao, H.Y.; Li, Y.H.; Song, Q.; Liu, S.C.; Ma, L.; Shu, X.Q. Catalytic reforming of volatiles from co-pyrolysis of lignite blended with corn straw over three iron ores: Effect of iron ore types on the product distribution, carbon-deposited iron ore reactivity and its mechanism. Fuel 2021, 286, 119398. [CrossRef]

20. Bagatini, M.C.; Kan, T.; Evans, T.J.; Strezov, V. Iron ore reduction by biomass volatiles. J. Sustain. Metall. 2021, 7, 215-226. [CrossRef]

21. Ni, M.; Leung, D.Y.C.; Leung, M.K.H.; Sumathy, K. An overview of hydrogen production from biomass. Fuel Process. Technol. 2006, 87, 461-472. [CrossRef]

22. Mousa, E.; Wang, C.; Riesbeck, J.; Larsson, M. Biomass applications in iron and steel industry: An overview of challenges and opportunities. Renew. Sustain. Energy Rev. 2016, 65, 1247-1266. [CrossRef]

23. Liu, J.; Yan, Y.; Zhang, H.P. Adsorption dynamics of toluene in composite bed with microfibrous entrapped activated carbon. Chem. Eng. J. 2011, 173, 456-462. [CrossRef]

24. Ren, L.; Zhou, S.; Peng, T.D.; Qu, X.M. A review of $\mathrm{CO}_{2}$ emissions reduction technologies and low-carbon development in the iron and steel industry focusing on China. Renew. Sustain. Energy Rev. 2021, 143, 110846. [CrossRef]

25. Wu, Y.J.; Zhang, H.P.; Yan, Y. High efficiency of phenol oxidation in a structured fixed bed over Cu-ZSM-5/PSSF prepared by ion-exchanged method. Chem. Eng. J. 2020, 380, 122466. [CrossRef]

26. Cholico-González, D.; Lara, N.O.; Miranda, M.A.S.; Estrella, R.M.; García, R.E.; Patiño, C.A.L. Efficient metallization of magnetite concentrate by reduction with agave bagasse as a source of reducing agents. Int. J. Miner. Metall. Mater. 2021, $28,603-611$. [CrossRef] 